\title{
PARENTAL Rights, BeSt InTERESTS AND SIGNIFICANT HARMS
}

\section{Cressida Auckland and Imogen Goold}

\begin{abstract}
Who should have the ultimate say over a child's medical treatment? A series of high-profile withdrawal of care cases have highlighted the full extent of the courts' authority to make decisions on behalf of children in the medical context. In both the Charlie Gard and Alfie Evans litigation, the courts have made clear that they have the power to make medical decisions for children at the point that child's welfare is engaged. All courts involved in both cases affirmed the orthodox position that the threshold for judicial intervention in disputes about medical care of children is the welfare of the child, often referred to as the 'best interests' approach (referring to both the threshold and the test applied to determine what should be done). While no new point of law has been decided in these cases, they are important in that they confirm just how expansive the inherent jurisdiction of the courts in such cases is, extending as far as to prevent parents from removing their child to another jurisdiction to pursue alternative treatment. In this paper, we argue that the current threshold for intervention is too low. We argue that prima facie decision-making authority about a child's medical care should rest with the child's parents, affording them the ability to choose between the range of medical options available. This authority should yield only where the parents' decision carries a 'serious risk of significant harm' to the child, at which point the court then has the authority to intervene. When it does so, the court should then apply the best interests approach.
\end{abstract}

\section{Key words}

Parental authority, parental decision-making, inherent jurisdiction, serious risk of significant harm, best interests. 


\section{INTRODUCTION}

In recent years, a series of high-profile disputes between the parents of very ill children and their child's medical practitioners have made their way through the courts. In such cases, all parties believe that the course of action they favour is what is best for the child, yet those parties cannot reach agreement. Some, such as $\operatorname{Gard}^{1}$ and Evans, ${ }^{2}$ involve the additional complexity of different medical teams offering alternative treatment or care options, and disputes arising over whether some of those options fall within responsible medical practice. The key question raised in all of these cases was who should have the ultimate say over a child's medical treatment? The courts have made it clear that they have the authority to make medical decisions on behalf of children and affirmed the orthodox position that the threshold for judicial intervention is the welfare of the child, often referred to as the 'best interests' approach (referring to both the threshold and the test applied). This raises deeper questions about the relationship between the state and its citizens, and the legitimate boundaries for state interference in family and private life.

In this paper, we argue that the current threshold for intervention is too low. We suggest that prima facie decision-making authority for a child's medical care should rest with the child's parents and not be too easily overridden. This is because many decisions about children are not solely medical decisions, but value decisions and taking respect for difference seriously means being committed to promoting a plurality of values. Where the decision about a child rests on these value-judgements, and where there is space for reasonable disagreement, there are good reasons to think that parents, due to their particular relationship to the child, should have the final say over a child's care unless there is a sufficient reason for them to be overridden. We argue for a 'significant harm' threshold, with parental authority yielding to the courts only when the parents' decision carries a serious risk of 'significant harm' to the child. Only once this threshold is satisfied should a 'best interests' evaluation be relevant as a means for the court to determine what should be done, resolving disputes between parents and medical professionals, and managing cases where parents wish to pursue a treatment that is harming, or indeed refuse treatment for their child altogether. We select this threshold because it better

\footnotetext{
${ }^{1}$ The case involving Charlie Gard is officially Great Ormond Street Hospital v Yates and Gard [2017] EWHC 972 (Fam) and so we refer to it as 'Gard' when referring to the decision and the litigation.

${ }^{2}$ Alder Hey Children's NHS Foundation Trust v Mr Thomas Evans, Ms Kate James, Alfie Evans (A Child by his Guardian CAFCASS Legal) [2018] EWHC 308 (Fam).
} 
reflects the boundaries between our private lives and those areas into which the state can rightly intervene, is the most ethically justified and strikes the most appropriate balance between parental authority and protecting the vulnerable. It would also more accurately reflect current practice. While it does echo the threshold proposed in Gard and also that in s. 31 of the Children Act 1989, it is the ethical justification that underpins our choice of threshold.

We begin by exploring why the recent case law has precipitated a debate on when the courts can legitimately make medical decisions on behalf of a child. We argue that the "best interest threshold" lacks sufficient justification and that the jurisprudence does not offer a sufficient normative basis for it. In doing so, we make an implicit challenge that if the courts are to maintain the current threshold, stronger justification needs to be offered. We briefly outline the reasons courts give to support the best interests threshold, before explaining why it is more defensible to raise the threshold for intervention in parental decisions, giving parents greater authority to make decisions about their children. However, we argue, this does not commit us to affording unbounded authority to parents, and we offer a number of reasons why this is so and hence why judicial intervention is still appropriate and justified in many cases. Children are vulnerable members of our community, and it is incumbent on us as a society to protect those who cannot protect themselves. A balance needs to be struck between offering such protection, while respecting parental authority and preventing illegitimate incursions into private and family life. In determining this balance, the 'serious risk of significant harm' threshold is the most widely accepted and legitimate alternative, and we therefore focus on making the case for its adoption (and examining the objections and challenges to doing so). ${ }^{3}$

\section{BACKGROUND}

In the past few years, a series of cases have brought attention to the way the courts manage disputes between parents and doctors over decisions about a child's medical care. The cases of

\footnotetext{
${ }^{3}$ In this paper, we focus only on children who are not 'Gillick-competent', that is those children whom the law regards as lack capacity to give consent to treatment. We do so to focus squarely on those cases where the parents or the court are required to decide entirely for the child. We do recognise that there are interesting questions to be asked about the interaction between the harm threshold and the approach the law takes to Gillick-competent children, but they are beyond the scope of this paper.
} 
Charlie Gard, Alfie Evans and Isaiah Haastrup ${ }^{4}$ all involved an application by the treating hospital for life-sustaining treatment to be withdrawn from a seriously ill child, a request which the parents vehemently resisted. Although they shared this common feature, the facts of each were importantly different. In Gard, the parents hoped to travel to the United States, where an alternative treating team was willing to provide an extremely experimental treatment to Charlie which, if successful, could extend his life and improve his condition to some degree. In the cases of Alfie Evans and Isaiah Haastrup, there was no suggestion of experimental treatment. Rather, the parents wanted a tracheotomy to be performed on the children and for artificial ventilation to be continued, in the hope of extending life a little further. The question in those cases was instead whether prolonging the life of a heavily brain-damaged and physically disabled child in circumstances where they would inevitably die before long was worth the harms associated with these invasive treatments. Given the factual similarities between these two cases, it is interesting to note how differently they played out. Perhaps due to the extensive media attention received, Alfie was offered the treatment by a hospital in Rome, with the result that the parents sought only for him to be permitted to travel to Italy to receive the treatment. In Haastrup, no other hospital offered treatment for Isaiah, so the parents instead requested that the hospital provide him with the tracheotomy themselves, before allowing him to return to his home where ventilation would continue. In all three cases, the parents' requests were denied by the courts, and the withdrawal of treatment was authorised as being in the child's best interests.

Although referred to in the Gard case and in much of the media response to the recent cases, the high-profile case of Ashya King in 2014 involved a very different kind of disagreement. The dispute over which type of radiotherapy treatment Ashya should receive (a conventional therapy or an experimental Proton one) involved a series of misunderstandings, but the crux of the issue related to whether the NHS would fund the experimental treatment abroad (given the lack of evidence to suggest that it would be more successful than the conventional treatment offered), rather than whether or not he should be prevented from travelling abroad. The parents' wish was therefore acceded to when alternative sources of funding were found.

\footnotetext{
${ }^{4}$ Kings College Hospital NHS Foundation Trust $v$ Ms Thomas, Mr Haastrup and Isaiah Haastrup [2018] EWHC 127 (Fam).
} 


\section{Why SHOULD We RETHINK THE 'BeST INTERESTS'}

\section{APPROACH?}

Disputes such as these are not new within hospitals or to the courts. Why, then, do we consider it time to rethink this settled approach? The cases of Alfie Evans, Charlie Gard, Ashya King and Isaac Haastrup have generated extensive media attention, not only in the UK, but around the world, precipitating considerable public concern and revealing a substantial disjunction between what the legal position is and what many people believe it ought to be: that parents should have the final say in decisions about their child's care. Thousands of people worldwide mobilised in protest at Alfie's treatment. A comment from one article on the Gard case provides a good example of how this view has been framed across social media:

No matter how skilled the doctors, this was NOT their decision to make, they should have recommended a course of action, of course, but NEVER ever should have they felt they had the right to impose their wishes over those of the parents. ${ }^{5}$

In response, Steven Woolfe MEP announced 'Alfie's Law', aimed at securing legal change to "restore the rights of parents in such decisions"; 6 while the parents of Charlie Gard have launched a similar initiative, "Charlie's Law", according to which the court's should only be permitted to intervene only where the parent's decision exposes their child to a risk of significant harm. ${ }^{7}$

However, it is not this attention alone, nor the high-level judicial decisions that should prompt us to re-evaluate the law - the strength of opposition among some members of the community is only an indicator that the law is in need of critical re-evaluation. In fact, these cases have

\footnotetext{
5 "Charlie Gard's parents refused permission to spend his last night at home before his life support machine is switched off on Friday", The Telegraph, 27 June 2017, available at <https://www.telegraph.co.uk/news/2017/06/29/charlie-gards-parents-refused-permission-spend-last-night-home/> accessed on 20 March 2019. Chris Gard, Charlie's father, has himself argued that 'our parental rights have been stripped away' by the court decisions, See M. Robinson et al., "Devastated parents of Charlie Gard spend their last night with their baby and blast 'heartless' doctors for refusing to let them take him home to die before they turn off his life support later today", The Daily Mail, 30 June 2017 <https://www.dailymail.co.uk/news/article-4653894/Outpouring-grief-worldwide-Baby-CharlieGard.html> accessed on 20 March 2019.

${ }^{6}$ ITV News, "MEP Launching Campaign for 'Alfie's Law' to give Parents more say", ITV News, 26 April 2018, available at <http://www.itv.com/news/granada/2018-04-26/mep-launching-campaignfor-alfies-law-to-give-parents-more-say/> accessed on 3 August 2018.

${ }^{7}$ The Charlie Gard Foundation, 'Charlie's Law'< https://www.thecharliegardfoundation.org/charlieslaw/> accessed on 4 August 2018.
} 
done more than simply stir up public sentiment: through them, the courts have revealed the full extent of their not hitherto apparent powers under the inherent jurisdiction, as well as highlighting the lack of robust normative justification for the current legal position.

The law on such matters has long been established, but prior to Gard, the question of when the court could intervene had never been clearly defined. The reason for this was simple: in almost every case where a dispute has arisen between the parents and the treating team, neither party could achieve their desired outcome without the court's assistance. The parents could not force an unwilling doctor to treat their child against their assessment of the child's best interest, nor could a doctor undertake treatment on the child in the absence of consent from either the parents or the courts. In all previous cases, therefore, an application was made to the court which had to 'arbitrate' between the positions of the two parties and determine what should happen.

The facts of Gard however, raised a novel question, as the parents were not trying to force GOSH to treat Charlie, they were merely asking for him to be allowed to be transferred to a different hospital in the United States, where another medical team was willing to provide the experimental 'nucleoside therapy'. Unlike in these previous cases therefore, there was no need for the Court to step in and provide its consent (or refusal of consent): treatment had been offered to Charlie, and his parents had consented to him receiving it. The question therefore became whether there ought to be a threshold that must be met before the court could interfere in the medical decisions of parents, and if so, what that threshold was. Counsel argued for the existence of a 'risk of significant harm' threshold, according to which the court could only intervene in a parent's decision where it exposed the child to a risk of serious harm. But in its short statement rejecting the application for leave to appeal, the Supreme Court did not engage explicitly with the question of whether a threshold currently exists, nor with what that threshold might be - Lady Hale merely asserted that parents' cannot demand treatment that was not in their child's best interests. ${ }^{8}$ This suggests the Court has authority to intervene wherever a parent makes a decision that the Court considers is not in the best interests of the child. If this were the case, then the threshold in medical decision-making for children under the inherent jurisdiction is potentially very low indeed.

\footnotetext{
8 'Lady Hale's explanation of the Supreme Court's decision', as delivered in Court on 8 June 2017 , available at $<$ https://www.supremecourt.uk/news/permission-to-appeal-hearing-in-the-matter-of-charlie-gard.html> accessed on 20 March 2019.
} 
The cases also demonstrated the breadth of the Court's authority to make decisions once that threshold has been met. It is well-established that the Court can make declarations about what care a child may or may not receive, but Gard and Evans raised the question of whether the court's powers under the inherent jurisdiction extended to issuing an injunction to prevent parents travelling abroad to seek alternative treatment. In Gard, McFarlane L.J. stated:

If necessary, and one hopes that the situation will not arise, such an order would be backed up by an injunction in due course; but, if so, it would be an injunction made by the court. ${ }^{9}$

Such a situation did not, in the end, materialise in Gard. However, in Evans, whilst neither the High Court nor the Court of Appeal spoke in terms of an injunction to prevent Alfie being taken to Italy for treatment, Mr Justice Hayden was clear that he was refusing the parents' application to "permit the child's immediate removal to Italy", ${ }^{10}$ a decision which was upheld by the Court of Appeal, further rejecting the argument that this breached EU free movement law. Therefore, it seems the courts considered their powers to extend to issuing an injunction, albeit they did not phrase the judgment in these terms.

It is both the low threshold for intervention and the breadth of its power once the Court is involved that sparked much of the public dissatisfaction, ${ }^{11}$ and which, we argue, require greater justification, given the degree to which they encroach into private and family life (Article 8) and freedom of thought, conscience and religion (Article 9) under the European Convention on Human Rights. ${ }^{12}$ If, as the court suggested in Gard and Evans, judges can decide upon any matter relating to a child's welfare and intervene wherever it disagrees with the parents' assessment of the child's best interests, this would be an exceptionally large intrusion by the State into the private decisions of parents. As Counsel for Charlie Gard's parents put it before the Supreme Court:

\footnotetext{
${ }^{9}$ Yates \& Anor v Great Ormond Street Hospital for Children NHS Foundation Trust \& Anor [2017] EWCA Civ 410, [2017] W.L.R.(D.) 391 at [117].

${ }^{10}$ See note 2 above, [8].

${ }^{11} \mathrm{We}$ appreciate that the reporting of these cases, leaves much to be desired and the mis-reporting of key facts exacerbated the sense of outrage. However, this does not change the fact that many still regarded the fact itself that the Court had power to intervene and to restrain the parents from removing their children as problematic.

${ }^{12}$ Article 9 has relevance due to the religious dimensions in some cases, particularly Evans and Haastrup.
} 
if the State can, without the highest of justification, intrude into so private an area of human life as a joint parental decision made about one's child's upbringing, the scope for protection against state interference afforded by our most basic constitutional values, as well as by Article 8 ECHR, is considerably eroded. ${ }^{13}$

We argue that a shift to a 'serious risk of significant harm' threshold strikes a more defensible balance between respecting parental authority and enabling the state to protect vulnerable children. To establish this position, we critically appraise the justifications given in the case law for the current approach and then demonstrate why they are insufficient.

\section{BEST INTERESTS THRESHOLD: ORTHODOXY AND ITS JUSTIFICATIONS}

As we have seen, the Courts in both Gard and Evans were clear that they have jurisdiction to intervene whenever a child's welfare is engaged such that it is possible their best interests may not be met. ${ }^{14}$ In doing, they offered some clarity about the threshold for intervention: the engagement of welfare represents the threshold, however welfare and a finding that a course of treatment is 'not in the child's best interests' are treated as synonymous.

It is unfortunate that the Court failed to provide any normative justification for this broad jurisdiction, nor to engage with the concerns raised, either in Gard, or in the Evans and Haastrup cases that followed. Such justification can be found in the earlier case law however, on which the Courts undoubtedly relied. Graeme Laurie traces the courts' parens patriae doctrine, the basis of the inherent jurisdiction, to feudal times, stemming from:

the monarch as the ultimate superior, empowered with jurisdiction ... over the administration of justice in those lands and, indeed, with jurisdiction over the very "person" of those who inhabited the land. In this latter respect the monarch was parens patriae -- parent of the country-and, as such, had the right and duty to care for those not able to care for themselves. ${ }^{15}$

\footnotetext{
${ }^{13}$ In the matter of Charlie Gard (Permission to Appeal Hearing), 8 June 2017 available at $<$ https://www.supremecourt.uk/news/permission-to-appeal-hearing-in-the-matter-of-charliegard.html> accessed on 20 March 2019.

${ }^{14}$ In the matter of Charlie Gard (Permission to Appeal Hearing), Thursday 8 June 2017; Judgment of the UK Supreme Court in the Case of Charlie Gard, 19 June 2017 at [13].

${ }^{15}$ Graeme T. Laurie, 'Parens Patriae Jurisdiction in the Medico-Legal Context: The Vagaries of Judicial Activism' (1999) 3 Edinburgh L. Rev. 95, 95.
} 
In England, he writes, this power was vested in the feudal lords until it was transferred to the courts in the sixteenth century. The courts still hold this parens patriae jurisdiction in relation to children. As early as 1848 , it was said in In Re Flynn that the court had this role so as to protect children from their parents' decisions where 'essential to their safety or to their welfare, in some very serious and important respect'. ${ }^{16}$ The jurisdiction's basis and scope were elucidated in $R v$ Gyngall in the late nineteenth century:

a paternal jurisdiction...in virtue of which the Chancery Court was put to act on behalf of the Crown, as being the guardian of all infants, in the place of a parent ... The Court is placed in a position by reason of the prerogative of the Crown to act as supreme parent of children, and must exercise that jurisdiction in the manner in which a wise, affectionate, and careful parent would act for the welfare of the child. ${ }^{17}$

Until the end of the nineteenth century this jurisdiction had been tempered by a belief that 'parents know best', but this view began to fall from favour. The Guardianship of Children Act 1886 equalised parental rights and made the "welfare of the child" a statutory factor, while the Custody of Children Act 1891 sections 1 and 2 gave the court the power to interfere with parental rights in the interests of the child. In 1893, it was made clear in In re McGrath (Infants) that:

The dominant matter for the consideration of the court is the welfare of the child ... the word welfare must be taken in its widest sense. The moral and religious welfare of the child must be considered as well as its physical well-being. Nor can the ties of affection be disregarded. ${ }^{18}$

This position was reiterated throughout the first half of the twentieth century, with statutory and case law developments, and by the time $J v C[1970]$ was decided, it was firmly established that the paramountcy of best interests ${ }^{19}$ had been secured, and parental rights had been subordinated to welfare. ${ }^{20}$ The key justification was the need to protect the child's welfare, with the clear elision of 'welfare' and 'best interests'. In $R e T$, Lord Justice Waite affirmed the welfare

\footnotetext{
${ }^{16}$ In re Flynn (1848) 2 De. G. \& Sm. 457, 474.

${ }^{17} R v$ Gyngall [1893] 2 Q.B. 232, 239, 241-242

${ }^{18}$ In re McGrath (Infants) [1893] 1 Ch. 143, 148.

${ }^{19}$ ibid, 710-711.

${ }^{20}$ J. v. C. [1970] A.C. 668, 697.
} 
approach and stated that the Court considers itself to have the authority to intervene whenever the child's best interests will otherwise not be promoted. ${ }^{21}$

The courts have nonetheless made clear that parents are still afforded power to make decisions for their children in relation to medical care. As outlined by Lord Scarman in Gillick $v$ West Norfolk and Wisbech Area Health Authority:

It is abundantly plain that the law recognises that there is a right and a duty of parents to determine whether or not to seek medical advice in respect of their child, and, having received advice, to give or withhold consent to medical treatment. ${ }^{22}$

Ward L.J. emphasised in Re A, that this position is affirmed by s.3 of the Children Act 1989, which gives:

Each of the parents... has parental responsibility over the child. That is defined, perhaps rather unsatisfactorily, in section 3 of the Act in these terms: "(1) In this Act 'parental responsibility" means all the rights, duties, powers, responsibilities and authority which by law a parent of a child has in relation to the child and his property". ${ }^{23}$

But, as Lord Scarman made clear in Gillick, 'the common law has never treated such rights as sovereign or beyond review and control', ${ }^{24}$ for as Ward L.J. explained, this parental authority 'exist[s] for the performance of their duties and responsibilities to the child' and hence 'must be exercised in the best interests of the child'. Therefore, 'overriding control is vested in the court'. Indeed, facing a similar public response to that seen in the Gard case, he felt the need to explain that:

This proposition is well established and has not been the subject of any challenge in this appeal. Because of the comment in the media questioning why the court should be involved, I add this short explanation. Long, long ago the sovereign's prerogative to protect infants passed to the Lord Chancellor and through him to the judges and it forms a part of the inherent jurisdiction of the High Court. The Children Act 1989 now contains a statutory scheme for the resolution of disputes affecting the upbringing of children. If a person having a recognisable interest brings such a dispute to the court, the court must decide it. ${ }^{25}$

\footnotetext{
${ }^{21}$ Re T (A Minor) (Wardship: Medical Treatment) [1997] 1 W.L.R. 242.

${ }^{22}$ Gillick $v$ West Norfolk and Wisbech Area Health Authority [1986] A.C. 112, per Lord Scarman at p. 184.

${ }^{23}$ Re A (Children) [2001] 1 Fam 147 (HL), [2001] 2 W.L.R. 480 per Ward L.J. at p. 178.

${ }^{24}$ Gillick [1986] AC 112, per Lord Scarman at p. 184.

${ }^{25}$ Re A (Children) [2001] 1 Fam 147 (HL), [2001] 2 W.L.R. 480 per Ward L.J at p. 178.
} 
That this position represented the current law had been thought comprehensively settled in Portsmouth Hospitals NHS Trust $v$ Wyatt in $2005 .{ }^{26}$ This case concerned challenges brought by the parents of a severely ill child to decisions made by medical practitioners about her future care, most pertinently the decision to put a 'do not resuscitate' order in place. Despite fierce debate in the media, Hedley J. was clear that it was the Court that had the final say over whether or not the order was maintained. The basis on which a determination should be made was whether or not it was in the child's best interests, but the mere performance of parental duties 'not in the child's best interests' could trigger court authority to intervene. 'Best interests' and 'welfare' are clearly treated as one and the same, and so the child's 'best interests' is understood as both the threshold for intervention, and as the approach to be taken when determining what should be done. ${ }^{27}$

When in Gard, Justice Francis considered he had jurisdiction to intervene therefore, he was acting in accordance with long-standing legal orthodoxy about the court's inherent jurisdiction. In applying the best interests test and concluding that continued life support or alternative treatment were not in Charlie's best interests, he was also taking a highly orthodox approach. It was consequently of little surprise when he was supported in this by the Court of Appeal and the Supreme Court, nor was it unexpected when the courts took the same approach in the later Evans case. $^{28}$

It is clear therefore that parents have authority to make medical decisions, subject to that authority being overridden by the courts at the point that welfare concerns are engaged. So, as Lady Hale states: 'parents are not entitled to insist upon treatment by anyone which is not in their child's best interests. ${ }^{29}$ Consequently, the position can be reduced to the view that parents shall speak, but if their decision conflicts intractably with that of the doctors', and if the matter

\footnotetext{
${ }^{26}$ [2005] EWCA Civ 1181.

${ }^{27}$ It should be noted that such a determination is to be made against the background position that a medical professional cannot be legally compelled to offer treatment that he or she is opposed to offering on clinical grounds, and doctors will rarely be required to administer treatment they do not believe is appropriate. Further, doctors mostly concur on what treatment is required, so disputes of the kind that arose in Yates rarely arise: $R$ (Burke) $v$ General Medical Council \& Ors [2005] EWCA Civ 1003 at [31]. See also, General Medical Council, 'Treatment and Care Towards the End of Life: Good Practice in Decision Making' (2010) at paragraph 14(d), available at <https://www.gmc-uk.org/ethical-guidance/ethical-guidance-for-doctors/treatment-and-care-towards-the-end-of-life > accessed on 20 March 2019.

${ }^{28}$ See note 2 above at [47]-[50].

29 'Lady Hale's explanation of the Supreme Court's decision', as delivered in Court on 8 June 2017 available at $<$ https://www.supremecourt.uk/news/permission-to-appeal-hearing-in-the-matter-of-charlie-gard.html> accessed on 20 March 2019.
} 
under dispute engages the child's welfare (as it almost always will), the court may legitimately step in and take over decision-making. This leaves a very large space into which the court is permitted to step. The elision of 'not in the child's best interests' with the 'engagement of welfare' sets a low bar because it means courts can intervene whenever a better decision might be made ('not in best interests') or the child's welfare is affected. 'Welfare' is effectively the lowest bar possible. 'Best interests' is somewhat higher but does not allow for tolerably suboptimal decisions. Both however set the bar low, and with welfare as the time-honoured and recently reiterated justification, it is clear that this is well-accepted by the courts.

\section{Challenging THE Best InTERESTS THRESHOLD}

Children, particularly the very young, cannot make healthcare decisions for themselves, and so this responsibility must fall on someone who can take those decisions, in the first instance, to the parents or legal guardians of the child. This cannot be an unbounded power: children are inherently vulnerable and this creates responsibilities for their protection on parents, but also the state (and arguably the community). There will inevitably be situations when an impasse arises about how to ensure that protection and, self-evidently, someone must take a decision to resolve the situation. The fundamental question is who? The court considers itself to be that final arbiter by reason of the need to protect children due to their vulnerability. It is this that (so the argument goes) justifies the authority the court exercises in the face of threats to welfare. Best interests therefore acts as justification, threshold and substantive test.

What is not self-evident, however, is that this is the right approach. By 'right', we mean most effective, in being the most likely to achieve a good outcome for the child; legitimate in terms of the balance struck under Article 8; and an approach that protects and promotes other, wider values where appropriate. It will now be considered therefore, whether the current threshold for intervention is correct, both in terms of ensuring the best decision is made for the child; and with respect to the balance it strikes between state and familial privacy. 


\section{A. Who is best able to decide what is in the child's best inter-}

$$
\text { ests? }
$$

What emerges from the case law, sometimes only implicitly, is that the courts regard themselves as having this authority because they are better placed or better able to make determinations than parents. They regard themselves as representing the child's interests and, in being prepared to override parents, must necessarily consider their view of the child's interests to trump even those of parents as committed to a child's interests as Connie Yates and Chris Gard. In this section, we explore whether this is likely to be the case. We approach this question first by considering why parents might be best placed to make decisions about their children and so should have prima facie authority for children's welfare decisions, followed by considering why even though this authority cannot be unlimited, the 'best interests' threshold is not the right point at which to limit this authority.

\section{PARENTS Should Be the Prima FACIE DeCISION- MAKER WITH REGARD TO CHILD MEDICAL MATTERS}

Despite sometimes being referred to as 'parental rights', parents do not have rights in the Holfeldian claim-right sense, but rather they have authority to make decisions that derives from their responsibility for the child. This alone does not answer why they stand in this position however, and the level of responsibility and authority they hold. ${ }^{30}$ That this authority is legally contingent on being exercised in the child's best interests was made clear by Lord Fraser in Gillick:

parental rights to control a child do not exist for the benefit of the parent. They exist for the benefit of the child and they are justified only in so far as they enable the parent to perform his duties towards the child, and towards other children in the family. ${ }^{31}$

Many parental decisions have an impact on their children, sometimes lasting and with potentially serious implications for their upbringing. These choices - which include medical decisions - are left to parents so as to avoid making substantial invasions into familial privacy by

\footnotetext{
${ }^{30}$ This language avoids the problem of distinguishing parental rights from other rights that differ in not-being self-regarding. We are grateful to Tristan Cummings for suggesting this point to us.

${ }^{31}$ Gillick $v$ West Norfolk and Wisbech Area Health Authority [1986] A.C. 112, per Lord Fraser at p. 170.
} 
monitoring these decisions and intervening regularly to police them. Such an approach would offend our general commitment to privacy and family life in liberal democratic society and practically, would require vast resources to administer, implement and police. As Joseph Goldstein writes, the law:

... as parens patriae the state is too crude an instrument to become an adequate substitute for parents. The legal system has neither the resources nor the sensitivity to respond to a growing child's ever-changing needs and demands. It does not have the capacity to deal on an individual basis with the consequences of its decisions or to act with the deliberate speed required by a child's sense of time and essential to his well-being. ${ }^{32}$

Further, many everyday decisions made on behalf of children do not require special skills: most adults can make these decisions relatively well and there is no reason to think that anyone else would likely do better. This does not mean that there are not better or worse decisions, but that most are not so complex or difficult that they cannot reasonably be taken by competent parents or guardians. Many of these decisions also do not, individually, have very large impacts on the child. Therefore, if some less optimal choices are made, this is not a serious cause for concern. This all also allows space for the reality that parents have different resources, must balance other considerations and also take account the needs of other children (and any other persons for whom they may have responsibility).

In relation to medical treatment however, the courts $d o$ have the resources to supervise, and the consequences for the child of having or not having treatment may well be grave. Nonetheless, even here, parents ought to retain a degree of authority. One reason is that the parents will often know their child best, and so will be best placed to know their preferences. Douglas Diekema rightly points out that most parents care about their children, and hence:

they will usually be better situated than others to understand the unique needs of their children, desire what's best for their children, and make decisions that are beneficial to their children. ${ }^{33}$

This, he comments, is a good reason to presumptively respect parental autonomy and family privacy. ${ }^{34}$ Rob Heywood makes a similar point, noting that because parents tend to know their children best, 'it is

\footnotetext{
32 J. Goldstein, "Medical Care for the Child at Risk on State Supervision of Parental Autonomy" Yale Law Journal (1977) 86(4), 645, 650.

${ }^{33}$ D. Diekema, "Parental Refusals of Medical Treatment: The Harm Principle as Threshold for State Intervention" (2004) 25(4) Philosophy of Medical Research and Practice 243, 244.

${ }^{34}$ ibid., 244.
} 
they who are best placed to make a decision about what is truly in their child's best interests is not implausible'. 35

Parental authority might also benefit the children in other ways. For example, Goldstein suggests that:

the right of parents to raise their children as they think best, free of coercive intervention, comports as well with each child's biological and psychological need for unthreatened and unbroken continuity of care by his parents. ${ }^{36}$

Furthermore, it is the parents who will ultimately bear the burdens that flow from the decision. Where, as is almost invariably the case, parents want treatment to continue, it is they who will carry the care burdens that may result. This would seem to be quite a strong reason for them to have a considerable say over what treatment the child receives. As Erica Salter puts it

Parents, as the central leaders and bearers of responsibility and accountability for the family, are also generally the central bearers of these decisional consequences. ${ }^{37}$

Salter argues that this, combined with parents' arguably greater knowledge of the child's needs and preferences, is sufficient to justify parental authority over their children. ${ }^{38}$

Diekema makes the further point that decisions about a child often affect other family members, and require that parents 'weigh the competing interests ... in making a final decision' ${ }^{39}$ Society values the family unit, and as Diekema argues, families need to be able to make decisions about themselves with some degree of autonomy and with 'sufficient space and freedom from intrusion from others' to flourish. ${ }^{40}$ In giving parents autonomy, the hope is that they will feel supported and respected, rather than policed, and hence exercise that autonomy with responsibility.

The value of according parents decisional autonomy may also be justified because it shows respect for pluralism. It enables parents to pass on particular views, values, and religious commitments to their children. In a liberal democracy committed to tolerance, this must be right. As Rob Heywood argues:

if the law is to take seriously views about freedom of religion, expression, and the right to respect for private and family life, it must attach genuine significance to medical decisions which are underpinned by those values, values which the English courts have only ever tipped their hats to in the evolving case law. ${ }^{41}$

\footnotetext{
${ }^{35}$ R. Heywood, "Parents and Medical Professionals: Conflict, Cooperation, and Best Interests" (2012) 20(1) Medical Law Review 29, 33.

${ }^{36}$ See note 32 above, 649.

${ }^{37}$ E. Salter, 'Deciding for a Child. a Comprehensive Analysis of the Best Interest Standard' (2012)

33(3) Theoretical Medicine and Bioethics 179, 181.

38 ibid.

${ }^{39}$ See note 33 above, 244.

40 ibid.

${ }^{41}$ See note 35 above, 33 .
} 
This commitment to liberal values is especially important where there is not a verifiably 'right' or 'wrong' answer about what is best for the child. Goldstein contends that:

It is precisely in those cases in which reasonable and responsible persons can and do disagree about whether the 'life' after treatment would be "worth living" or "normal", and thus about what is "right," that parents must remain free of coercive state intervention in deciding whether to consent to or reject the medical program proffered for their child. ${ }^{42}$

His point is that if there can be reasonable disagreement, then the parental view cannot be 'wrong' (nor any other answer 'right') because there is no one objectively right answer. It is in such circumstances that 'the law's guarantee of freedom of belief becomes meaningful and the right to act on that belief as an autonomous parent becomes operative within the privacy of one's family'. ${ }^{43}$ In such cases, the law should protect this freedom by leaving these decisions to parents.

The Gard case is an apt factual situation to explore this point because the key issue was whether the potential harm from undergoing nucleoside therapy was worth the improvements Charlie might possibly gain from it. It was a decision about which chances are worth taking and at what cost, about which there cannot be a 'right' or 'wrong' answer. Emily Harrop offers a similar example in the case of spinal muscular atrophy type 1 , in which a treatment that might slow the course of the disease is available, but delivery of the treatment is unpleasant and the future benefits are uncertain. She explains that

The decision is a very personal one; for example, when two families who had made opposite decisions happened to visit our hospice at the same time, neither regretted their choice, when faced with the other. ${ }^{44}$

There is no clear answer to questions such as quality of life versus longevity. Such a decision is really a harm/benefit analysis, in which life extension and possible improvement must be weighed against immediate harms, chance of success and potentially worse outcomes. Beyond clearly harmful situations that threaten the child's life, a great many such decisions about what is best for a child are questions of values (and to a degree, relate to subjective preferences if the child is old enough to have formed these): to know what is in the child's best interests in the face of competing courses of action, we need to know which values we think it is best to pursue. Given this, then absent other considerations, parents are at least as well placed as others to make these determinations. Leaving such decisions to parents supports their authority and promotes respect for difference. To do otherwise, in the absence of a strong countervailing

\footnotetext{
${ }^{42}$ See note 32 above, 654.

${ }^{43}$ Ibid, 655.

${ }^{44}$ E. Harrop, 'Setting the Scene: Supporting and Informing Shared Decision-Making at the Bedside'

In I. Goold, J. Herring and C. Auckland (eds.), Parental Rights, Best Interests and Significant Harms. Medical Decision-Making on Behalf of Children Post-Great Ormond Street Hospital v Gard, (2019 forthcoming). See also E. Salter, 'Deciding for a Child. a Comprehensive Analysis of the Best Interest Standard' (2012) 33(3) Theoretical Medicine and Bioethics 179, 191 and the case of Aaron in her discussion.
} 
consideration, effectively gives primacy of one view on value over another. Such a determination both lacks justification and fails to protect tolerance of difference.

The parent's insight may be of particular value when there is a need to balance medical considerations against other interests, which is reflected in the current law. Diekema offers the illuminating example of chemotherapy:

Although medical considerations are important, a child's interests will also be affected by emotional and physical accompaniments of the chosen course. Best interests all too frequently may be reduced to objective medical interests alone. In discussing chemotherapy for a child with leukaemia, for example, medical professionals frequently focus on the fact that therapy will increase the child's chance of survival while underestimating the negative aspects of cancer treatment. Some parents may place greater weight on the risks, side effects, discomforts, and disruptions that the child may endure in being treated, perhaps making the judgment that the increased chance of survival does not justify those burdens. Determining how these multiple factors ought to be weighed is no simple matter. ${ }^{45}$

The welfare of the child is a matter in which emotional, religious, cultural and family considerations are all intimately connected. Parents are therefore uniquely positioned to assess the child's medical interests in light of these other important considerations.

These latter points have extra importance where the child was old enough to have expressed preferences before losing capacity. In such cases, parents may also be best placed to reflect the child's perspective, as they have insights that other parties lack. Essentially, they have empirical information that is highly relevant to the question of what is best for the child. Where this is not the case, then even their knowledge of the family's value, the wider context in which the child will be raised and so on, suggest that respecting parental authority is likely to produce a decision that will best promote the child's interests.

For all of these reasons, then, there is a substantial case in support of the law according parents a wide margin of discretion in order to make medical treatments on behalf of their children. ${ }^{46}$

\footnotetext{
${ }^{45}$ See note 33 above, 248.

${ }^{46} \mathrm{We}$ note that our analysis rests largely on a presumption that parents are engaged, loving and want the best for their children. We appreciate that this is not always the case, but consider it sufficiently usual that parents have their child's best interests at heart to ground this position. In case where parents are not so engaged, some problematic choices may be caught by a harm threshold, while educational provision and child social services may redress some other concerns. We also note the judicial acceptance that some variation in parenting is the price of tolerance (see comments of Hedley $\mathrm{J}$ in $R e$ $L$ : "Society must be willing to tolerate very diverse standards of parenting, including the eccentric, the barely adequate and the inconsistent": Re L (Care: Threshold Criteria) (2007) 1 F.L.R. 2050).
} 


\section{1. $\quad$ The Limits of Parental Responsibility and Authority}

While parents will very often choose well enough for their children therefore, there will always be exceptional cases, where the parent's decision should not be upheld and the court should have power to intervene. There must, therefore, be some limit on parental authority. This limit should be set at least at the point of what Loretta Kopelman's calls 'a justifiable threshold of adequate parenting' ${ }^{47}$ This, she points out, requires us to determine 'what harms or risks of harm are sufficient, in magnitude and probability, to justify the restriction of the guardians' choice' ${ }^{48}$ To delineate these limits, we must first consider the different reasons parents might disagree with the recommendations of medical professionals such that court intervention is even a consideration. This will enable us to determine what the limits of parental authority should be in respect of such disputes.

Sometimes, parents may disagree with medical professionals about something that is open to proof - a dispute of fact. In Re Ashya King for example, while both parents and doctors accepted that Ashya needed chemotherapy and radiotherapy, the dispute related to the extent and type of treatment. The parents argued for Proton radiotherapy that causes less radiation damage, but for Ashya, both therapies needed to be used on the entire brain and spine and therefore any benefits, as a matter of fact, would be limited. ${ }^{49}$ The disagreement was thus largely about the evidence in support of the treatment the parents wanted and its likely efficacy in achieving the benefits they sought.

In some cases, parents will make decisions which are based on verifiably wrong or unconvincing evidence. Only last year for example, a seven-month-old baby in Belgium died of malnutrition and dehydration after being fed a gluten-free and reduced-lactose diet by his parents. ${ }^{50} \mathrm{In}$ less extreme cases, one party (generally the parents) may be mistaken about a matter of fact, perhaps because they lack the medical training to fully understand information relevant to the decision. Or parents may lose trust in their doctors and no longer accept the truth of what they

\footnotetext{
${ }^{47}$ L. M. Kopelman, "The Best-Interests Standard as Threshold, Ideal, and Standard of Reasonableness" (1997) 22 The Journal of Medicine and Philosophy 271, 276.

48 ibid.

${ }^{49}$ Re Ashya King [2014] EWHC 2964 (Fam) at [5]-[10].

${ }^{50} \mathrm{~K}$. McLaughlin and G. Davies, "Health food zealot parents blamed for starving child's death walk free: Baby died after his organs shrank in HALF because Belgian couple fed him a gluten-free and quinoa milk diet", The Daily Mail, 14 June 2017 available at <http://www.dailymail.co.uk/news/article-4604100/Parents-blamed-starving-child-s-death-walk-free.html> accessed on 1 July 2018.
} 
tell them. In the case of Isaiah Haastrup for example, the parents simply would not accept the medical facts about his prognosis put forward both by the treating team, and the independent experts they themselves had appointed. Mr Justice Macdonald wrote:

The mother makes clear in her statement that, contrary to the medical evidence, the parents do not accept that it is not possible to wean Isaiah off his ventilator. Whilst accepting that a number of attempts have been made and that these were not successful, the mother and the father believe that the medication that Isaiah is being given is having an effect on his ability to breath on his own and that, were it not for this, he would recover his ability to breath on his own. They are each unable to accept the medical evidence that the level of damage to the respiratory centres of Isaiah's brain is of such magnitude that this will not be the outcome for Isaiah. ${ }^{51}$

Similar concerns were raised in respect of his level of consciousness (the mother believed that "the sole driver of changes in Isaiah's alertness is the level of his medication"52); his visual and aural functioning (which were reputedly not carried out at the 'optimal' time), ${ }^{53}$ and his responsiveness. There was fundamental disagreement between the parties over the fact of his current level of functioning.

In disputes of this kind, we argue that there is only a need for intervention where the factual dispute (or error) will harm this child. Parents make errors of fact about many things, but most make little difference to a child's life and are insufficient to justify the privacy infringements of overriding those decisions. But a factual error that causes harm to a child cannot be acceptable. There is nothing about a factual error that lends justification to harming a child, and the justifications for parental authority do not offer any basis for respecting their decision in such cases. A parent cannot claim a right 'to be wrong' in such cases. A relatively low bar for intervention might then be justified in such cases, but some form of pre-court mediation and measures to help address the errors of fact made by either party would be welcome.

In other cases, parents' decisions may be open to challenge because the parents may be unable to make a decision in their child's best interests because they are too biased to do so, either because their decision is clouded by their beliefs or because of their interest in their relationship with the child. Sometimes, this will mean their authority should be fettered and intervention would be justified to bring objectivity to the decision-making process given that it affects a vulnerable third party in the person of the child. Somewhat paradoxically, the depth of a parent's relationship with her child is raised as both the reason she is likely to know her child's

\footnotetext{
${ }^{51}$ See note 4 above at [58].

${ }^{52} \mathrm{ibid}$ at [59].

${ }^{53} \mathrm{ibid}$ at [60].
} 
needs and interests best, and the reason why she is too closely connected to the child's situation to decide objectively. Putting pressure on the claim that parents do in fact know the child best, Salter notes that the parent-child relation is emotionally complex and:

may not be conducive to full and frank disclosure of the child's preferences to parents. This complexity is often aggravated in times of illness and crisis, sometimes causing children to feel guilty, helpless, abandoned, or embarrassed. Indeed, oftentimes, children are able to be more straightforward with someone with whom they have a different kind of relationship. ${ }^{54}$

A parent may not then possess more information than others about a child's preferences, or the information shared with them by the child may actually be misleading. Similarly, Salter explains, this emotional complexity may mean the other claims made for parental authority - that parents best understand how their child thinks, and can work out what he or she would want is flawed for the same reasons. ${ }^{55}$ Such arguments also lack weight in cases of very young children and infants.

Bias and emotionality on the part of a parent is not alone enough for their decision to be overridden but it is a basis on which we can say that sometimes we might question their authority in relation to a particular decision. This might be in cases where emotion blinds the parents to be able to accept factual information, or to take on board the evaluations of the treating team. In such instances, it could be said that emotionality may be undermining the parents' capacity to make rational decisions, and so provide a basis on which to believe that other parties might be better able to weigh the relevant information. But merely the fact that parents are emotionally involved in their children's lives is not itself a sufficient reason to assume that the court or the medical professionals know what is best.

In some situations, meanwhile, parents may have an inherent conflict of interest, such as where they must choose between the interests of two children - one needs a kidney, the other is a potential donor. Robert Bennett notes that, 'a judge may be asked to intercede because the parent's conflict of interest makes him an inappropriate decision-maker' ${ }^{56}$ State intervention

\footnotetext{
54 See note 37 above, 181.

55 ibid, 181.

${ }^{56}$ R. Bennett, “Allocation of Child Medical Care Decision Making Authority A Suggested Interest Analysis” (1997) 62(2) Virginia Law Review 186, 313.
} 
is desirable, even necessary, where parents cannot agree on what is best for a child, as otherwise no determinative choice about how to proceed can be made. ${ }^{57}$

Most often the difficult cases that challenge the courts and put pressure on where the right line for intervention lies however, concern disputes not of fact, but of value or belief. Of these, disputes of belief are difficult precisely because they test our commitment to respect for plurality of values, pitting our commitment to respect for belief against the communal responsibility for the vulnerable in our society. Disputes of value are in some ways less complex once we see them as such. We deal with each in turn now.

Disputes based on belief are those where parents may rely on something other than the medical facts to form their opinion of what should happen to the child. In the United States, numerous cases have come before the courts in which parents have failed to obtain medical help for their children for religious reasons, including a series of murder and manslaughter charges ${ }^{58} \mathrm{~A}$ girl in Idaho was left permanently and seriously disabled after her parents refused surgery to close a small congenital hole in her heart in favour of prayer for example ${ }^{59}$ prompting a taskforce to estimate that the child mortality rate for followers of that sect was ten times that of Idaho as a whole over an eight year time period. ${ }^{60}$

In England and Wales, the courts have been challenged many times by cases involving the religious beliefs of parents. For example, the refusal of the parents to authorise the separation of conjoined twins in Re A (Children) (Conjoined Twins: Surgical Separation), ${ }^{61}$ was borne out of the couples' strong Catholic beliefs, while the courts have on a number of occasions

${ }^{57}$ See, e.g., $F v F$ [2013] EWHC 2683 (Fam). Parents disagree over whether their children should receive certain vaccinations. Once the court has intervened in these cases, they must apply a best interests test to determine which, of the different courses of action available, ought to be pursued.

${ }^{58}$ See for example: M. Sampathkumar, "Parents who prayed for sick daughter instead of taking her to hospital charged with murder", The Independent, 7 June 2017 available at <https://www.independent.co.uk/news/world/americas/oregon-parents-prayer-daughter-dies-arrested-charged-murdera7777646.html> accessed on 1 July 2018; "Faith-healing parents charged with MURDER after second child died in their home from pneumonia without getting medical help while they were on probation over death of first son", Daily Mail, 22 May 2013 available at <http://www.dailymail.co.uk/news/article-2329305/Faith-healing-parents-charged-MURDER-second-child-died-home-pneumonia-gettingmedical-help-probation-death-son.html> accessed on 1 July 2018.

${ }^{59} \mathrm{~J}$. Wilson, "Letting them die: parents refuse medical help for children in the name of Christ", The Guardian, 13 April 2016 (accessed 1 July 2018), https://www.theguardian.com/usnews/2016/apr/13/followers-of-christ-idaho-religious-sect-child-mortality-refusing-medical-help ${ }^{60}$ The Governor's Task Force on Children at Risk, 1 July 2015 available at <http://idahochildren.org/wp-content/uploads/2014/12/IDCARTFtoOtter.pdf.> accessed on 20 March 2019. ${ }^{61}$ [2001] 2 WLR 480. 
been asked to adjudicate on the issue of Jehovah's Witness parents refusing blood transfusions for their children. ${ }^{62}$ Such cases are difficult to resolve, given their profound implications for the child, who cannot speak for themselves and who has not yet the competence to determine his or her own religious views. We argue that the religious views of the parents are not themselves sufficient to justify unlimited parental authority in such cases, precisely because they involve the imposition of religious views on another person (the child) where the consequences (which may be significant) are borne by that other person. Indeed, the concept of children's rights is important in this context, as it reminds us that the child is a rights-bearer and this includes not having religious beliefs he or she does not clearly hold imposed upon him or her in a way that may affect their future life. For this reason, such decisions are not accommodated by Article 9 (respect for belief) alone. However, if we are serious about our commitment to plurality and respect for belief, religious views alone are not sufficient for parents' views to be overturned either, even if they have some small impact on welfare. These are the kinds of cases that demonstrate why 'best interests' is an inadequate threshold, as it permits intervention even on the smallest welfare encroachment and allows for the overriding of religious views on weak grounds, undermining the law's commitment to freedom of belief.

Disputes of value, by contrast, do not present the same difficulties once understood in this way. These involve views about which kinds of chances are worth taking, ${ }^{63}$ about what is important in life or which benefits are worth which burdens. For example, this may be a question of whether it is preferable to live for longer but endure some pain or indignity, or live for less time but with more of what one regards as good quality of life. Such disagreements are not about facts, but about what makes a good life, and therefore they are not of a kind that any one person is necessarily better placed to decide. By their very nature, they permit of more than one legitimate view, precisely because they entail considerations that are subjective and which always have a personal dimension.

As Lord Justice Waite put it in $R e T$, disputes of value exist on a scale:

at one end of which lies the clear case where parental opposition to medical intervention is prompted by scruple or dogma of a kind which is patently irreconcilable with principles of child health and welfare widely accepted by the generality of mankind; and that at the other end lie

\footnotetext{
${ }^{62}$ See for example: Re E (A Minor) (Wardship: Medical Treatment) [1993] 1 FLR 386).

${ }^{63} \mathrm{We}$ are grateful to Jonathan Herring for suggesting we consider the distinction between mistakes of fact and disputes about value.
} 
highly problematic cases where there is genuine scope for a difference of view between parent and judge. ${ }^{64}$

In his Lordship's view, in both situations it is 'the duty of the judge to allow the court's own opinion to prevail in the perceived paramount interests of the child concerned', but that in cases where there was real scope for disagreement, the court should be influenced by 'a reflection that in the last analysis the best interests of every child include an expectation that difficult decisions affecting the length and quality of its life will be taken for it by the parent to whom its care has been entrusted by nature'. ${ }^{65}$ This has meant that the courts take account of parental views insofar as possible.

The Gard case could be framed as a disagreement about the likelihood that the treatment would have any efficacy, but given the weight of opinion and evidence on one side, it is better seen as a dispute over which chances are worth taking and at what cost. Where a 'chance' is regarded as virtually nil, this may move from being a balance of evidence to a belief in near miracles. That said, this does not mean that taking a small chance is necessarily irrational or mistaken. As Julian Savulescu has argued:

if [the odds] are not zero, why not have a trial of treatment for several months, or a year, under strict pain control (which we are told is so effective in palliative care)? The parents seemed to accept that Charlie's current state was not one which was worth prolonging and if no progress was made, one could stipulate that treatment must be withdrawn... Is a month or year of experimental treatment that offers a slim chance of improvement clearly against his interests? ${ }^{66}$

Cases that are the end of Lord Justice Waite's scale are those where we can still say parental authority should be subject to limits, but they are also those where the best interests threshold begins to demand more justification. Where there is room for reasonable disagreement, there is essentially no right or 'best' answer, and so the question of 'best interests' cannot be properly answered. Or, at the least, there is no clear reason why the court is any better placed to make this determination for the child than his or her parents. This was, to some extent, the issue in Gard and one which, with respect, both the Court of Appeal and the Supreme Court avoided.

${ }^{64}$ Re T (A Minor) (Wardship: Medical Treatment) [1997] 1 W.L.R 242, 253-254 per Waite L.J.

${ }^{65}$ ibid.

${ }^{66}$ J. Savulescu, "Debate: The Fiction of an Interest in Death? Justice for Charlie Gard", JME Blog, 26 April 2017 available at <https://blogs.bmj.com/medical-ethics/2017/04/26/debate-the-fiction-of-aninterest-in-death-justice-for-charlie-gard/> accessed on 20 March 2019. 
It was even more squarely the case in Evans, which was concerned precisely with what constitutes a good death, a question of values rather than fact. ${ }^{67}$ This critique of 'best interests' holds both for its use as a threshold for intervention, and as a test generally to determine what should be done. However, we are concerned only with the issue of a threshold in this paper. ${ }^{68}$

Some limits on parental authority are needed, but setting the threshold for intervention at 'welfare' or 'decisions not in the child's best interests' permits the court the authority to override decisions too easily. We take the view, like Diekema, that in a libertarian society we should maintain respect plurality of values insofar as is possible, and that it should be more than mere impact on welfare that tips the balance too far from respecting differences of viewpoint in our society.

Further, we argue that the best interests threshold lacks clarity as a point for intervention precisely because it is possible that there is no answer to the question of what is in the child's best interests - there may be multiple legitimate, sufficient or reasonable answers. As Lynn Gillam has put it, best interests is a 'notoriously subjective and grey concept', even 'when used in legal context by a judge' ${ }^{69}$ In fact, the very notion that 'best' forms part of the threshold, means that if the court claims authority to intervene, it is implicit that the court is regarded as "best" able to determine what to do. It is not self-evident that the court is best placed in relation to parents, and arguments could be made for doctors in the context of some disputes, particularly factbased ones. It is therefore not clear that the court has any basis on which to claim greater authority that parents or doctors. Indeed, of the three potential decision makers, the court arguably lacks both medical expertise and experience of similar situations at close hand, and the subjective knowledge of the child of the parents - its only real claim is to be an objective observer, which is not itself limited to the court and does not alone confer sufficient authority.

\footnotetext{
${ }^{67} \mathrm{We}$ are grateful to an anonymous reviewer for raising this aspect of the Evans litigation to us. ${ }^{68}$ There is considerable defence of the best interests approach to determining what should be done in the case law as outlined earlier in this paper, and a body of critique in the ethics and medical law literature but it is beyond the scope of this paper to explore that literature here. See further: R. Heywood, "Parents and Medical Professionals: Conflict, Cooperation, and Best Interests" (2012) 20 Medical Law Review 29; L. Gillam, "The Zone of Parental Discretion: An Ethical Tool for Dealing with Disagreement between Parents and Doctors about Medical Treatment for a Child" (2016) 11(1) Clinical Ethics 1.

${ }^{69} \mathrm{ibid}$.
} 


\section{B. $\quad$ The limits of state intervention under Article 8}

The right to respect for one's 'private and family life' is explicitly protected by Article 8 of the European Convention on Human Rights. The right is qualified, and subject to restrictions made 'in accordance with law' where 'necessary in a democratic society' for 'the protection of health or morals, or for the protection of the rights and freedoms of others' ${ }^{70}$ But on the basis of the right, as well as protections in the United Nations Convention on the Rights of Children, legally parents have prima facie authority to make intimate medical decisions for their children, and the Strasbourg court has been clear that medical intervention on a child without the parent's consent constitutes a violation of Article 8, subject to some qualifications. ${ }^{71}$ In acknowledging that Article 8 could apply in Gard, Lady Hale was clear in response that according to Strasbourg jurisprudence, any conflict between the rights of parent and child under Article 8 ought to be resolved in favour of the child. We think this is surely right. For the reasons given above, permitting parents to act as unrestricted rights-bearers with regard to their children, with the power to make any decisions no matter the impact goes against our communal commitment to protecting the vulnerable from unacceptable harm.

However, we need to be clear about what constitutes a 'conflict' between the parents and children for these purposes. The fact a parent is in dispute with doctors does not itself mean that the parents are in 'conflict' with the child, absent any negative affect to the child's rights. As explored above, there are a variety of ways in which parents may disagree with doctors, not all of which necessarily entail a 'conflict' with the child. The parents are acting in the way that they think best promotes the interests of that child, even if the doctors or court disagree. The requisite 'conflict' is therefore not necessarily indicated by parent-doctor disputes, and so the Court's authority to involve itself in decisions that fall within the scope of Article 8 is not invoked simply because parents and doctors disagree. Lady Hale did not therefore, with respect, resolve the issue of when the court could intervene in private family decisions.

\footnotetext{
${ }^{70}$ Convention for the Protection of Human Rights and Fundamental Freedoms (European Convention on Human Rights, as amended) (ECHR) art 8(2).

${ }^{71}$ MAK and RK v United Kingdom (Application Nos 45901/05 and 40146/06), European Court of Human Rights March 23, 2010. See also the protection of parental rights in Articles 3(2) and 5, United Nations Convention on the Rights of Children.
} 
The question then, is whether intervening on the basis that the decision is not in the child's best interests can be said to be 'necessary' for the protection of the child's health according to Article 8 . If so, this seems to be an exceptionally large intrusion by the State into the private decisions of parents. As counsel for the appellants in Gard, Richard Gordon QC, explained:

If best interests were to be relevant touchstone, the distinction between legitimate state action and the discharge of parental responsibility would disappear since any action by parents with which court disagreed could be overruled. ${ }^{72}$

In the jurisprudence on Article 8, 'necessary' has been taken to imply 'the existence of a pressing social need" for the interference'. ${ }^{73}$ Moreover, in Dudgeon v United Kingdom, the European Court of Human Rights was clear that

According to the Court's case-law, a restriction on a Convention right cannot be regarded as "necessary in a democratic society" - two hallmarks of which are tolerance and broadmindedness - unless, amongst other things, it is proportionate to the legitimate aim pursued. ${ }^{74}$

If best interest determinations involve a weighting of interests or factors which may legitimately be balanced differently by different people, then in any given situation, there is room for reasonable disagreement, including between the parents and the Court. The current law would thus seem to go beyond what is 'necessary' to serve it aims of protecting children from harm, as it enables the Court to override the decisions of parents merely because they disagree with the parents balancing of interests, even where the child is not being exposed to such harm. Such interference may therefore be disproportionate to its aim, especially when considered in light of the importance attached to 'tolerance and broadmindedness' in a democratic society.

In approaching these questions, we also need to ensure that the matter of children's rights is not left aside. Rachel Taylor emphasises that "the first important principle of parental responsibility is that the parental role is one of responsibility to children rather than proprietary rights over them". ${ }^{75}$ She points out that parents are to exercise those responsibilities in a manner that

\footnotetext{
72 'Lady Hale's explanation of the Supreme Court's decision', as delivered in Court on 8 June 2017 available at $<$ https://www.supremecourt.uk/news/permission-to-appeal-hearing-in-the-matter-of-charlie-gard.html> accessed on 20 March 2019.

${ }^{73}$ Dudgeon v United Kingdom (1983) 5 EHRR 573, [51].

74 ibid.

${ }^{75}$ R. Taylor, "Parental Decisions and Court Jurisdiction: Best Interests or Significant Harm?" in I. Goold, J. Herring and C. Auckland (eds.), Parental Rights, Best Interests and Significant Harms. Medical Decision-Making on Behalf of Children Post-Great Ormond Street Hospital v Gard, (2019 forthcoming).
} 
guides the child in the exercise of his or her own rights, which accords with the approach to the rights of the child in the UN Convention on the Rights of the Child. ${ }^{76}$ Taylor reminds us of Lord Scarman's point in Gillick that:

'[W]hen a court has before it a question as to the care and upbringing of a child it must treat the welfare of the child as the paramount consideration in determining the order to be made. There is here a principle which limits and governs the exercise of parental rights of custody, care and control. It is a principle perfectly consistent with the law's recognition of the parent as the natural guardian of the child: but it is also a warning that parental right must be exercised in accordance with the welfare principle and can be challenged, even overridden, if it be not. ${ }^{, 77}$

This, Taylor rightly argues, implies that when a parent acts outside this responsibility and wants to act in a way that undermines a child's welfare, this affords the state the authority to intervene on the child's behalf. This is in fact "vital to establishing the child as a person with their own rights and interests recognised and protected in law". ${ }^{78} \mathrm{We}$ entirely agree with this analysis, but would then argue that a move to a harm threshold does not in any sense undermine that child's rights, it merely sets the point at which welfare has been affected slightly higher than de minimis, affording parents a margin for difference but still ensuring that the state can protect the child when his or her welfare is threatened to the extent that justifies intervention. This reflects the actual point at which courts intervene in medical decision disputes, for as Taylor points out, the courts use judgment to permit for reasonable variation in parenting. A higher threshold would better reflect this acceptance that there is a range of reasonable parenting.

We can understand this range partly by what we discuss above --- that there can be very finely balanced and difficult disputes about what is best for a child where neither option is harming relative to the other. Such disputes are generally about values. They do not necessarily mean there is a dispute in which one of the choices affects the child's health to a degree that it necessitates 'protection' (when compared with the alternative). To accept otherwise would, as Gordon explained, lead one:

into quicksand, because the distinction between parental responsibility, what a parent can decide, is subject to the supervisory control of the state, in every single aspect... ${ }^{79}$

At the very least therefore, Article 8 lends weight to the need for greater justification for the best interests threshold, which arguably affords the court a supervisory power well beyond the

\footnotetext{
${ }^{76}$ See further ibid.

${ }^{77}$ Gillick v. West Norfolk and Wisbech Area Health Authority [1986] AC 112 at p 184.

${ }^{78}$ See further note 75 above.

${ }^{79}$ See note 13 above.
} 
legitimate bounds of the state's authority to intervene in our private and familial lives. More fundamentally however, it might also support a move to a harm threshold, as given the requirement that restrictions on parental decision-making must be necessary and proportionate, it is difficult to conceive of state intervention being 'necessary' in the absence of harm to the child. In the next section, we will argue that while a 'serious harm' threshold has its own problems, it does at least offer greater direction and clarity.

\section{ARGUMENTS FOR MOVING TO A ‘SERIOUS RISK OF SIGNIFICANT HARM’ THRESHOLD}

The authority to make healthcare decisions about a child should prima facie rest with parents, showing respect for a plurality of values and freedom of belief, and recognising the unique role of parents in a child's life. Such authority cannot however be unbounded, yet the best interests threshold is not the right limit. In this section, we therefore make the case for why a threshold of significant harm is more appropriate and legitimate than the current welfare threshold.

At the heart of Gard and Yates' appeal was the idea that there should be 'both priority and protection to the privileged position of a parent ${ }^{80}$ The test would, in certain cases, operate on a presumption that parents' views would be decisive, unless it could be shown that doing so would produce significant harm to the child. We have considerable sympathy for this position, and agree that parents should remain prima facie decision-makers. However, in our view, a notion of parents as 'privileged' goes too far. Parents should be conceptualised as having a privilege related to their responsibility so that there must be a clear, albeit higher, bar when this must yield.

The most appropriate threshold for intervention, in our view, is where the parent's choice would expose the child to the risk of suffering significant harm. This balances our commitment to liberty and the need to protect children and reflects the liberal democratic values of the English legal system. Douglas Diekema argues that parenting is a basic liberty, a view with which we concur for the reasons given above ${ }^{81}$ and proposes such a threshold as the appropriate one for the United States courts to use:

${ }^{80}$ Great Ormond Street Hospital v Yates [2017] EWCA Civ 410, [58].

${ }^{81}$ ibid. 
The parens patriae doctrine recognizes that society has an obligation to ensure that the basic needs of its most vulnerable members are met. In general, parental decisions should be accepted except in those rare cases where the decision of a parent places the child at substantial risk of serious harm. In these cases, the state acts in loco parentis, in the place of the parents. While this role of the state has been recognized as constitutionally valid, in the U.S. courts have closely examined such actions, showing reluctance to require medical treatment over the objection of parents 'except where immediate action is necessary or where the potential for harm is rather serious' ${ }^{82}$

As Diekema argues, if parenting is a basic liberty, following the harm principle, only harm to others justifies the curtailment of a liberty right, and this must be an effective last resort. ${ }^{83}$ Persistent failure to satisfy a child's basic needs is a harm, and only when this threshold is passed is intervention justified ${ }^{84}$ Despite the claimant's in Gard proposing a similar 'risk of significant harm' threshold in both the Court of Appeal and the Supreme Court, this was rejected with little discussion. The Court of Appeal found the legal basis for this threshold unconvincing based on its evaluation of King and the Children Act 1989. The Supreme Court simply asserted its jurisdiction to intervene. While this response would suggest both courts put relatively little stock in such a threshold, in fact significant harm has considerable support in the ethical literature. McDougall and Notini point out from a systematic review of the ethical literature that: "most bio-ethicists argue that harm is a better threshold. There is a consensus on this issue. ${ }^{\prime 85}$

According to this approach, 'parents are free to discharge parental responsibilities by making decisions in respect of their children unless the purported discharge thereof would cause their child significant harm'. ${ }^{86}$ This protects a zone of decision-making: the parents' decision about what is "best" for their child would be followed, providing that it wasn't considered significantly harmful. Where there is space for reasonable disagreement, and where the decision rests in the balancing of multiple factors without exposing the child to significant harm, it seems right to permit leeway to parents and give them the final say, respecting their unique responsibility for the child and their deep personal interest in his or her wellbeing. Certainly, this would better accommodate the importance of parents having substantial control and a wide margin

\footnotetext{
${ }^{82}$ See note 33 above, $250-1$.

83 ibid.

${ }^{84}$ ibid.

${ }^{85}$ R.J. McDougall and L. Notini, "Overriding Parents' Medical Decisions for their Children: A Systematic Review of Normative Literature" (2014) 40 J Med Ethics 448, 52.

86 'Lady Hale's explanation of the Supreme Court's decision', as delivered in Court on 8 June 2017 available at $<$ https://www.supremecourt.uk/news/permission-to-appeal-hearing-in-the-matter-of-charlie-gard.html> accessed on 20 March 2019.
} 
over their child's care, for whom they have a special responsibility and emotional connection. This operates in a middle ground between respecting a plurality of values, differences of viewpoint and freedom of belief and protecting the child's interests in life-changing medical decisions. In doing so, the law may also accord better with public expectations, providing better justification for its intervention - harm - as opposed to appearing as if parents are not best placed to determine what is best for their child.

One argument put forward in the Gard case for the risk of significant harm was that it would be consistent with the approach taken in relation to care decisions, where section 31 of the Children Act 1989 prevents a court from making a public law order placing a child in the care of, or under the supervision of, a local authority, unless the court is satisfied that the child is suffering or is likely to suffer significant harm, or likelihood of harm. Introducing a significant harm threshold therefore would ensure a consistent approach to the question of when the State can intervene in a child's upbringing, which may ensure greater clarity about what the legal position is, and how to apply it. The jurisprudence on the application of s31, in particular over what constitutes sufficiently serious harm, will undoubtedly help inform the application of the threshold in the medical context. But this is not a sufficient reason itself for shifting the threshold in medical decision-making cases.

Section 31 involves situations of a different kind and the implications of crossing the threshold differ as they permit a child to be taken into care. Given the huge variation in opinion over how it is best to raise a child, the high threshold for care decisions is necessary if we are to offer any protection of plurality of values. The sheer quantity of different, but reasonable views about questions such as the lifestyle, education, and religious or others values to live by, means that anything other than a high threshold would leave no space for disagreement. Not only would this be impossible to countenance in a liberal democracy committed to religious freedom and tolerance, but it would be undesirable, given the value we attach to having a society in which individuals develop their own unique identities and sense of what is important to them, based on different cultural, religious and social values. ${ }^{87}$ Furthermore, the fact that s31 orders can be incredibly disruptive to the child, provides a good reason for there being an extremely high threshold before local authorities can intervene. Indeed, the Children Act was partly devised

\footnotetext{
${ }^{87}$ The Christian Institute and others (Appellants) v The Lord Advocate (Respondent) (Scotland) [2016] UKSC 51.
} 
with a view to stopping the over-zealous behaviour of local authorities, which were too readily involving themselves in family life prior to 1989. As MacFarlane L.J. explained in Gard:

Prior to the Children Act coming into force, local authorities had regularly resorted to the inherent jurisdiction of the High Court in order to achieve some form of control over the lives of individual children and their families. A clear purpose of the 1989 Act was to close down or at least limit that avenue and to channel all such cases through the statutory scheme embodied in Section 31 of the Act, which requires the state in the guise of a local authority to satisfy the court that the significant harm threshold criteria are established before the court can consider going on to make orders to give the local authority power to control the life of an individual child in a family. ${ }^{88}$

While these concerns remain valid in the medical context, they have different traction because concerns about disruption to the family and child, while relevant, apply differently where a child is already in some way injured or unwell, and a decision is being taken about how best to alleviate or cure this injury or illness. Further, it is less obviously and pressingly important to allow for plurality of values in respect of most, but not all, medical decisions. Protecting a sphere of independence for a parent to decide whether or not to vaccinate their child, or what form of antibiotics to take, are less clearly important at a societal level than protecting freedom to decide how to educate their child, or what religion to raise them in.

However, the very sorts of decisions that usually give rise to serious disputes, are also those for which respecting the parent's values and beliefs are the most important. There is no more deeply personal or intimate issue than how and when to die; and respecting the parent's wishes, or religious beliefs in these circumstances is undisputedly as important as a child's education or diet. As Ronald Dworkin suggests, 'making someone die in a way that others approve, but he believes a horrifying contradiction to his life, is a devastating, odious form of tyranny'. ${ }^{89}$ There can be few decisions more important than those about how a person's life plays out. If we are committed to freedom over how parents raise their children, it would seem odd to not attach the same degree of importance to end of life decisions, as well as those which also touch so fundamentally upon a person's religious beliefs or other values. Such decisions are rarely purely medical in nature: the question of what point active treatment should be replaced with palliative care is to a large extent a value judgment and depends on many factors including what the person's religious beliefs or values, and their view of what will happen to the child.

${ }^{88}$ Yates \& Anor v Great Ormond Street Hospital For Children NHS Foundation Trust \& Anor [2017] EWCA Civ 410 at [107].

${ }^{89}$ R. Dworkin, Life's Dominion: An Argument About Abortion and Euthanasia, and Individual Freedom (New York 1993) 217. 
In these instances, therefore, respecting a plurality of values is a strong reason to accord parents with prima facie parental authority. Typically, the law's response in such cases has been to allow people to make these decisions for themselves (providing they have capacity), but not for those for whom they have parental responsibility. While a Jehovah's Witness may refuse a blood transfusion for themselves, they cannot refuse one for their child..$^{90}$ It is less obvious that this distinction ought to be the case in the absence of serious harm.

\section{A. Problems with the Harm Threshold}

Adopting a harm threshold is not without its problems. First, the very nature of the dispute in cases like Gard and Evans makes determining whether the child will suffer 'significant harm' incredibly difficult. The question of whether it is 'harmful' to keep someone alive in order to attempt experimental treatment or that which will only extend their life for a short time, is an inherently subjective question, which will be influenced by the person's culture, religious beliefs, and social matrix. Nor will the currency by which you measure harm be consistent. While pain and distress may be more easy to test for and quantify (although these cases demonstrate the problems even with trying to determine this), there are many other things which people experience as 'harmful' which are less tangible, for example causing distress to others, or going against deeply held religious beliefs. Trying to find a common currency to weigh up whether an action would be sufficiently 'harmful' is therefore challenging. For some, the perceived 'harm' may even extend to what happens after death' particularly in cases where parents hold strong religious beliefs. ${ }^{91}$ On what basis, does the court prefer the harm of pain and suffering during life, to eternal damnation after death? If a risk of significant harm threshold were adopted, much of the inquiry would be a discussion of what is meant by 'harm' and how much of it is necessary to be 'significant'.

\footnotetext{
${ }^{90}$ For example, Re E (A Minor) (Wardship: Medical Treatment) [1993] 1 FLR 386 and Re L (Medical Treatment: Gillick Competency) [1998]. See also, the US case of Prince v Massachusetts (1944) 321 US 158: "Parents may be free to become martyrs themselves. But it does not follow that they are free, in identical circumstances, to make martyrs of their children".

${ }^{91}$ The refusal of the parents to authorise the separation of conjoined twins in Re A (Children) (Conjoined Twins: Surgical Separation [2001] 2 WLR 480 for example, was borne out of their Catholic beliefs, while the courts have on a number of occasions been asked to adjudicate on the issue of Jehovah's Witness parents refusing blood transfusions for their children (see for example Re E (A Minor) (Wardship: Medical Treatment) [1993] 1 FLR 386).
} 
While there will undoubtedly be borderline cases over which there is disagreement, that does not mean that consensus will not be achieved in most cases. Although the United States courts, have for some time taken divergent approaches to the boundaries of parental decision-making, despite the prevalent language of best interests, ${ }^{92}$ Diekema argues the threshold operated in substance is generally the point at which the child will suffer harm. This suggests significant harm is capable of being used in practice, a view supported by its use in other contexts such as care proceedings. Indeed, Diekema argues that harm is much better understood by clinicians (and, as others have suggested, judges and parents), than best interests, ${ }^{93}$ and it might be regarded as easier to determine whether something is "harmful" (a negative) than whether something is the "best" decision for someone (a positive), such that there may well be greater consensus. Rebecca Dresser offers the example of male circumcision for religious purposes: while there is clearly disagreement over whether or not it is in a child's best interests to be circumcised, it is nonetheless considered insufficiently harmful by most legal systems to be prohibited..$^{94}$

However, even in cases where there is agreement over what constitutes harm, there may still be the problem of establishing whether the child in question is actually suffering that harm. The problem in Evans, and to a lesser extent in Gard, was that there simply was not sufficient evidence about whether or not the child was experiencing pain, or even was capable of feeling pain or not. How ought we to address situations where the harm is uncertain? We argue that, when in doubt, we must err on the side of caution, and any uncertainty ought to be resolved by assuming that there is harm. However, this tempered by two factors. First, that the risk of harm must be serious. Second, that the harm must be significant, and implicitly when determining what amounts to 'significant' harm courts should take sensible account of the fact that any medical treatment will involve some potential for pain or discomfort - even for something relatively minor, such as a vaccination. Too readily deeming something as significant harm, would risk diluting threshold down to little more than the best interests one.

\footnotetext{
92 ibid., 249. Also see above n50 and K. DeVille and L. Kopelman, "Fetal Protection in Wisconsin's Revised Child Abuse Law: Right Goal, Wrong Remedy" (1999) 27(4) Journal of Law, Medicine and Ethics 332, 335.

${ }^{93}$ See note 33 above.

${ }^{94}$ R. Dresser, "Standards for Family Decisions: Replacing Best Interests with Harm Prevention" (2003) 3 American Journal of Bioethics 54, 54.
} 
There may, of course, be some objection that this leaves parents effectively free to submit their children to some harm. However, in the medical context parental choices are constrained by what doctors are prepared to offer as treatments. Under English law, doctors cannot be compelled to treat nor can patients (or parents) demand treatments. ${ }^{95}$ Doctors' choices are bounded by the Bolam standard, which renders medical care that falls outside the range of responsible medical practice negligent. ${ }^{96}$ Following Bolitho, that standard also demands that the doctor's proposed course of action has a defensible basis, which limits access to choices that are without some clinical justification. Only decisions that conform with a reasonable body of professional opinion, and are not unreasonable or illogical, would therefore be open to parents. ${ }^{97}$ Even in a case like Gard, this could ground the court's decision to prevent a child from being taken overseas if the medical practitioner outside the country was offering treatment considered to fall below the Bolam standard. ${ }^{98}$

More fundamentally, however, a meaningful commitment to pluralism means we must sometimes allow parents to make decisions that expose children to low-level harms. Every day, parents make sub-optimal decisions: unhealthy food, fizzy drinks, or even uncontrolled online access. These may all expose the child to some risk of harm, and yet we allow parents to make those decisions, even where there is no obvious benefit. In the medical context too, we must trust parents to make these decisions and respect the reasons they have for choosing as they do. The uncomfortable reality of pluralism is that we must allow people to make decisions that we consider problematic, based on values and priorities that we do not accept or endorse, providing those decisions are not significantly harmful.

Diekema uses the example of the Delaware Supreme Court decision in Newmark $v$ Williams ${ }^{99}$ in which the parent's desire to refuse chemotherapy treatment for their son was upheld on the basis that even though the treatment had a $40 \%$ chance of success, the parents' weighting of this versus the risks and burdens of the treatment was accepted. The treatment was not so beneficial (relative to the burdens), that failure to give it would cause the child a sufficient degree

\footnotetext{
${ }^{95} R$ (Burke) v General Medical Council \& Ors [2005] EWCA Civ 1003.

${ }^{96}$ Bolam v Friern Hospital Management Committee [1957] 1 WLR 582.

${ }^{97}$ Bolitho $v$ City and Hackney Health Authority [1996] 4 All ER 771.

${ }^{98} \mathrm{We}$ are grateful to Professor Jonathan Herring for directing us to think about this point.

${ }^{99}$ Newmark $v$ Williams, Del Super Ct 588: A.2d 1108 (1991).
} 
of harm as to justify overriding the parents' decision. Diekema viewed this as an instance of the operation of a harm threshold in a case in which there was a legitimate basis for leaving such a balancing to parents rather than the court. ${ }^{100}$ This is in stark contrast to the decisions in which religious fundamentalists have caused the death of their child by rejecting any medical interventions whatsoever because of their belief in faith healing. Here the significant harm threshold would step in.

One remaining difficulty relates to the extent to which harm ought to be measured relative to the potential outcome. In cases such as Evans and Haastrup, the treatment sought was a tracheotomy followed by continued ventilation. While invasive and capable of causing discomfort, this was no different from that which many children receive each year, in order to sustain their life and enable them to recover and breathe independently. It was not, in this sense, any more painful or uncomfortable for Alfie or Isaiah than for anyone else. It was simply that in most cases this 'harm' is offset by clear benefits. However, here, there was an extremely low prospect of any meaningful improvement. 'Harmfulness' in these cases cannot be evaluated in isolation from the context and consequences of the treatment decision, but it is important for the court not to be unduly influenced by their perception of whether the treatment outcome is desirable. Otherwise, the inquiry risks becoming circular, simply meaning that we do not consider the outcome being pursued to be worthwhile. For example, if one considers it is significantly harmful to do this to a child who is very unlikely to ever permanently recover because they will not gain any meaningful benefit and only burdens, then the question simply becomes, what constitutes a meaningful benefit? For many, a prolonged life in a heavily disabled state may not constitute a 'benefit' but for Alfie's parents, prolongation of life was in itself a good outcome. For this reason, the argument for not being too conservative in characterising harm as 'significant' cannot be overestimated. A small amount of discomfort does not become significantly harmful just because the child is not going to live for long. To aid in this determination, Diekema poses a series of helpful questions aimed at establishing what might constitute sufficient serious risk and sufficient significant harm, which include whether the harm is imminent, whether the intervention refused is necessary to prevent that harm, and whether the benefits of the intervention more heavily outweigh its burdens than the balance achieved by the parents' preferred course of action. ${ }^{101}$

${ }^{100}$ See note 33 above, 256.

${ }^{101}$ See note 33 above, 252. 
Some commentators have suggested that adopting a significant harm threshold would actually pose a more explicit challenge to parental authority. As Giles Birchley argues, there is a risk that this involves greater 'evaluative overtones', ${ }^{102}$ so that the court would be required to interrogate the validity of their reasoning-process, before overtly overriding it if the judge does not accept the views expressed or reasons given. It would also explicitly characterise their decision as 'harmful', which might have 'pejorative connotations' ${ }^{103}$ and create additional distress, framing the decisions of loving parents as a type of 'abuse or neglect'. Rachel Taylor suggests that "it would be unnecessarily cruel and combative to require loving and sincere parents to defend themselves against a test based on harm unless required to do so". ${ }^{104}$ Katie Gollop and Sarah Pope similarly suggest that:

It's bad enough to have a court finding that what you wanted for your child was not in your child's best interests. It's worse to have a court finding that you have caused your child significant harm. ${ }^{105}$

These concerns may be fair, but we might also wonder whether the semantics would have much difference to the parents who, at the end of the day, are being overridden and effectively told that they are mistaken about what is best for their terribly ill child for whom they are fighting. We should not lightly brush off the impact of our words, but we should consider whether the potential they have to harm one set of parents is worth the trade off if it increases the autonomy of other parents. Furthermore, it is clear from the public reaction that many parents found the prospect of a court suggesting that they did not know what was best for their child, and someone else was better placed to decide this than them equally damaging. Therefore, this argument does not appear sufficient in itself to outweigh the benefits to parents in terms of their enhanced decision-making powers.

If, however, an undesirable impact on how the process of joint decision-making and consensus building occurs, this might be a reason to avoid moving to a harm threshold. Two ways in

\footnotetext{
${ }^{102}$ G. Birchley, “The Harm Threshold and Parents' Obligation to Benefit their Children” (2016) 42 Journal of Medical Ethics 111, 113.

103 ibid.

${ }^{104}$ See note 75 above.

${ }^{105}$ K. Gollop and S. Pope, "Charlie Gard, Alfie Evans and R (A Child): Why A Medical Treatment Significant Harm Test Would Hinder Not Help", (Transparency Project 28/05/2018) < http://www.transparencyproject.org.uk/charlie-gard-alfie-evans-and-r-a-child-why-a-medical-treatment-significant-harm-test-would-hinder-not-help/> accessed on 20 March 2019.
} 
which such an impact might occur have been suggested. The first potential impact that might be caused by a shift to a harm threshold is if it led parents to avoid disagreeing with medical professionals for fear that a case against them might be built to support a finding of risk of significant harm. Gollop and Pope suggest that parents might be more like to avoid the appearance of resistance, and indeed acquiesce to the wishes of the hospital when they might have preferred to discuss options for longer. ${ }^{106}$ They argue that this might be understandable given what happened in $R e R .{ }^{107}$ In that case, a Local Authority instituted care proceedings under the Children Act 1989 in response to concerns raised by the treating hospital after R's mother had taken a number of decisions that suggested she felt it was in R's best interests to be allowed to die. The treating team, the Local Authority and (when later consulted) Great Ormond Street Hospital, were of the view that $\mathrm{R}$ was not at the end of life and treatment should continue. ${ }^{108}$ Gollop and Pope explain that once the Local Authority had chosen to institute care proceedings as the means to ensure $\mathrm{R}$ continued to receive treatment, this meant they needed to pass the 'significant harm' threshold laid down in Section 31(2)(a) of the Children Act. This, they report, meant that

the Local Authority used every occasion on which R's mother had not accepted medical advice to build its case on significant harm. Each occasion on which she had differed with doctors, her refusal to alter the wishes document, the midazolam incident, her public statements (the ethical advice she asked for not having been provided) that $\mathrm{R}$ was suffering and ought to have treatment withdrawn - these were all invoked against her. ${ }^{109}$

They argue that:

If a significant harm test were introduced into children's medical treatment decisions, that could be dangerous for parents. If there are already concerns about whether the child's parenting is good enough, then any failure to accept medical advice will slot in to the existing significant harm case building exercise. ${ }^{110}$

They further argue that once a case of 'significant harm' was built in this context, it might put the Local Authority on notice about the child's care generally and begin building a case in support of a care order. They suggest it potentially have a "chilling effect', deterring parents who feel at risk of their child being taken into care from refusing treatments for fear of having

106 ibid.
107 ibid.
108 ibid.
${ }^{109}$ ibid.
${ }^{110}$ ibid. 
those decisions used against them in care proceedings. ${ }^{111}$ This may be particularly problematic where there is space reasonable disagreement about treatment options, as it may push parents to accept options they would prefer to reject where that rejection is not itself harmful. ${ }^{112}$

Were this to be the case, then indeed the move to a 'significant harm' threshold to strengthen parental rights might have the ironic impact of reducing their freedom to make decisions they believe to be best for their children if they fear having these invoked against them. It would be a very sad and deep irony if the very steps taken to increase parental autonomy ended up actually reducing their capacity to express their wishes about their child.

But we need to be careful about assuming too much about how parents will respond. Merely resisting some advice from the treating team is unlikely to inspire a Local Authority to institute care proceedings without more reason to be concerned about a child's welfare. Where a matter can be more directly resolved via intervention merely in relation to the treatment decision, and there was no other evidence to suggest a lack of care generally, we should not be too quick to assume that a Local Authority will be eager to institute care proceedings. While this was the case in $R e R$, the very fact that the final hearing was much more favourable to the mother than the Authority's actions would have predicted it would be, is perhaps a lesson to over-eager Local Authorities not to take such dramatic steps without sufficient evidence of a wider lack of care. Further, while some parents' decisions might be affected, this assumption relies on them having fears of how a Local Authority might respond, which seems unlikely in most cases. Also, as much of the case law indicates, a parent who is fighting for their child's survival and who disagrees with a medical decision is not likely to be easily cowed and hence we should not assume there will be such a chilling effect without further indications that this is likely to happen.

The other potential impact is on the place of parents in the decision-making process and the way the treating team and legal team (once brought in) must approach them. By establishing parents as having prima facie decision-making power that yields on when their decision poses a serious risk of significant harm, the medical team are reduced to advisors to the ultimate

\footnotetext{
111 ibid.

${ }^{112}$ See further on reasonable disagreement in D. Wilkinson, "In Defense of a Conditional Harm Threshold Test for Paediatric Decision-Making" in I. Goold, J. Herring and C. Auckland (eds.), Parental Rights, Best Interests and Significant Harms. Medical Decision-Making on Behalf of Children Post-Great Ormond Street Hospital v Gard, (2019 forthcoming).
} 
decision-makers (parents or court), as opposed to part of a collaborative team of parents, medical professionals and (if needed) the court, all working to determine how best to aid a child in need. As Glossop and Pope comment, and this echoes points made by Giles Birchley ${ }^{113}$ and others,

In disputes as long running and polarised as those in Gard and Evans, the atmosphere can become strained to breaking point. But everyone in the hospital is still always, and at all times of the day and night, striving to listen to, empathise with and be there for everyone in the family.

We might think, as they do, that "it's hard to see how the concept of significant harm might help with that". ${ }^{114}$ These intuitions have been echoed to the authors by medical professionals, although some also felt being able to refer to a more blunt explanation as to why the parents' wishes would not be met would be welcome. ${ }^{115}$

Gollop and Pope suggest that a harm threshold approach will effectively "require the hospital to pivot away from its sole core purpose - the care of its patients - towards child protection", and "would turn an inquisitorial process, where everyone assists the court in its task of identifying where the child's best interests lie, into an adversarial one". Once a conflict arose, rather than working towards consensus-building as is currently the case, the hospital (and lawyers) would need to begin building the case for overriding the wishes of parents - by establishing that their wishes posed a serious risk of significant harm to the child. Not only would this have the harming, stigmatising effects noted above, it would also mean that "positions would harden unnecessarily and dialogue would be more difficult. Mediation would have less, not more, chance of success." 116

However, for these arguments to convince, there needs to be much greater empirical support that there would be such an impact. Perhaps some parents might attempt to 'stand on their rights', but they might then be reminded that the law sees them as having responsibilities and

\footnotetext{
${ }^{113}$ G. Birchley, "The Harm Threshold: A View from the Clinic" in I. Goold, J. Herring and C. Auckland (eds.), Parental Rights, Best Interests and Significant Harms. Medical Decision-Making on Behalf of Children Post-Great Ormond Street Hospital v Gard, (2019 forthcoming).

${ }^{114}$ See note 105 above.

115 The authors are grateful to the audience who attended the Baron de Lancey lecture, given by Imogen Goold at the University of Cambridge in March 2019. This paper reflects the valuable input of many of those who made comments and asked questions. Dr Goold would like to thank the organisers Kathleen Liddell and Jeff Scopek, and the Ver Heyden de Lancey Fund for facilitating the event.

${ }^{116}$ See note 105 above.
} 
authority, rather than rights. ${ }^{117}$ More importantly, before any impasse is reached, conversations about care can proceed as they do now --- collaboratively, with medical team and parents working together to find the best course of action for the particular child. There is no reason this needs to change even if the law changes. Once relations break down or an intractable disagreement arises, as it did in Gard and Evans, whatever words one uses, the point at which there is any thought of judicial intervention is the point at which there is already a view by the treating team that the parents' wishes pose a serious risk of significant harm to the child. This is reflected in the findings of Giles Birchley and others empirical work, and echoed in some of Dominic Wilkinson's writing on the realities of when medical teams resist parental requests. ${ }^{118}$ As both note, doctors often acquiesce to parental requests if they are non-harming and even sub-optimal, but they resist (and request judicial support) when there is a risk of harm. Actual practice then, is in keeping with the ethical position outlined above - allow for difference of opinion where there is space for reasonable disagreement, but not once it exposes a child to harm for insufficient benefit or reason.

Therefore, when doctors do have disagreements with parents, and when matters are taken to the court, harm is very much at issue. This was evident in the evaluation of the evidence in Gard, where concern was raised about the harm Charlie might experience if moved to the United States. In the High Court for example, Hedley J raised concerns that the nucleoside therapy may 'subject the patient to pain, possibly even to mutations', ${ }^{119}$ while McFarlane L.J. was clear in the Court of Appeal that

to move Charlie to America and expose him to treatment over there would be likely to expose him to continued pain, suffering and distress. ${ }^{120}$

Changing the legal threshold, then, would simply reflect what is actually on the table when the court's intervention is requested (by either side), without affecting the early stages of clinical discussions with parents. ${ }^{121}$ The harm-building case must already be happening when the possibility of judicial intervention is on the horizon, both because this is the reason the medical team are likely to be opposing the parents in the first place, and also because this is the basis,

\footnotetext{
${ }^{117}$ As Lord Scarman emphasised in Gillick, see note 22 at p.184.

118 See notes 112 and 113 above.

119 Great Ormond Street Hospital v Yates and Gard [2017] EWHC 972 (Fam) at [22].

${ }^{120}$ Great Ormond Street Hospital v Yates [2017] EWCA Civ 410 at [114].

${ }^{121}$ We appreciate that this might be rebutted by those in practice (medical and legal), and suggest further research on this question would be welcome.
} 
in most cases, for the court taking the view that what the parents want is not in the child's best interests. 'Harm' might be understood very broadly in the best interests evaluation, and bring in notions of dignity, for example. But as the courts do not raise scarcity of resources as an aspect of best interests (rightly), the key determining factor must be (and is) harm because otherwise nothing is left on the other side of the balancing exercise to speak again what the parents want. Of course, the hospital cannot be required to offer treatment it does not think is appropriate, ${ }^{122}$ but this was not the issue in either Gard or Evans. Rather, it was concern about harm (in some sense) to those children that was at the heart of the matter. ${ }^{123}$ On this basis, while the concern raised here has weight, it requires more empirical support for it to be strong enough to overturn the arguments made in favour of the move to a harm threshold.

\section{CONCLUSION}

Resolving disputes of the kind that arose in the Gard, Evans and Haastrup cases will never be easy, and striking the right balance between respecting parental authority and protecting children will always be fraught with complexity. It is right that the courts play a role in ensuring children are given adequate, appropriate care. But we, as a society, must also find a way to walk the line between protection and tolerance of difference of views. The current 'best interests' threshold has worked well in many cases, but it is time for a shift to a 'significant harm' threshold to better respect parents' responsibility and authority in relation to their children. The court will still have the authority to protect children from harmful decisions, just as they currently do, and as doctors tend only to bring cases of the most serious, problematic kind to court, it is unlikely such a shift will bring change in some cases. But it will signal that the law takes respect for parental authority seriously, and draw the more appropriate boundary around the state's authority to involve itself in our lives. In cases where there is a vexed dispute over value but no serious risk of significant harm to the child, shifting to a harm threshold may make all the difference in ensuring that the court is not able to substitute its views about what is right for a child for those of the child's parents merely because it feels it knows better what is best

\footnotetext{
${ }^{122}$ And note Jo Bridgeman's valuable argument that we should understand cases like Gard as ones involving professional conscience: J. Bridgeman, "Beyond Best Interests: A Question of Professional Conscience?" in I. Goold, J. Herring and C. Auckland (eds.), Parental Rights, Best Interests and Significant Harms. Medical Decision-Making on Behalf of Children Post-Great Ormond Street Hospital v Gard, (2019 forthcoming).

${ }^{123}$ See notes 119 and 120 above. See also note 2 above, at [24].
} 
for the child. By drawing the line at significant harm, we make a real commitment to respect for differences of value, while still protecting children when they need it. 